INTERNATIONAL JOURNAL OF MULTIDisciplinARY RESEARCH AND ANALYSis

ISSN(print): 2643-9840, ISSN(online): 2643-9875

Volume 04 Issue 12 December 2021

DOI: 10.47191/ijmra/v4-i12-26, Impact Factor: 6.072

Page No.- 1952-1961

\title{
Spatio-Temporal Assessment of Vegetation Cover Dynamics in the Kurmi Region of Taraba State, Nigeria
}

\author{
Joshua, Maaku Mark', Ojeh, Nduka Vincent ${ }^{2}$, Atuma, Ifeanyi Morrison ${ }^{3}$, Akpoduado Ovie \\ Christiana ${ }^{4}$, Arisabor Lucky ${ }^{5}$, Idakwo Iko-Ojo Victor ${ }^{6}$ \\ 1,2Department of Geography, Faculty of Social Science, Taraba State University, Jalingo, Nigeria \\ ${ }^{3}$ Department of Arts and Humanities, Delta State Polytechnic, Ogwashi-Uku, Delta State \\ ${ }^{4,5}$ Department of Meteorology and Climate Change, Nigeria Maritime University, Okerenkoko, Delta State. \\ ${ }^{6}$ Department of Urban and Regional Planning, University of Maiduguri, Borno State
}

\begin{abstract}
The study was conducted on the Spatio-temporal assessment of vegetation cover dynamics in the Kurmi Region of Taraba State, in the Savannah belt of Nigeria, using remotely sensed satellite data from LANDSAT and the Geographic Information System. The result shows that from 2010 to 2015, there was an increase in none vegetative areas (Builtup, Barren, Rock, sand) by $6.1 \%$ and a reduction of vegetation by $6.1 \%$, also from the year 2015 to 2020 , there was an increase in the none vegetative areas (Builtup, Barren, Rock, sand) by $17.9 \%$ and reduction of vegetation by $17.9 \%$, while from 2010 to 2020 there was an increase in none vegetative areas (Builtup, Barren, Rock, sand) by $24 \%$ and reduction of vegetation by $24 \%$. Thus, the results of this study confirm that Spatio-temporal assessment of vegetation cover dynamics using NDVI by LANDSAT TM, ETM+ and OLI data offer an excellent potential tool for characterizing and understanding vegetation changes occurring in transitional areas like the Kurmi region of Taraba State. Furthermore, the study recommended that alternative domestic energy sources, e.g. kerosene, be provided to the low-income earners to avoid over-dependence on fuelwood sourced from deforestation.
\end{abstract}

KEYWORDS: DEFORESTATION, NDVI, GIS, LANDSAT, KURMI, TARABA STATE

\section{INTRODUCTION}

The vegetation cover works as a thermal barrier between the atmosphere and the ground, and it helps to redistribute snow cover. The vegetation cover works as a thermal barrier between the atmosphere and the ground, and it helps to redistribute snow cover. Globally, there is a notable high increase in the need to reduce forest loss and, in turn, pursue sustainable development pathways (Ajiola \& llesanmi, 2017). This is because forest ecosystems provide a range of essential services for human well-being (Kalaba et al., 2013; Paumgarten and Shackleton, 2011).

According to millennium Ecosystem Assessment(MA), a study aimed at providing insight into the status of global ecosystems reported that two-thirds of ecosystem globally has been in decline (MEA, 2005). The importance of ecosystems in livelihoods, coupled with the reportedly high rates of ecosystem degradation, has led to an increase in research framed around ecosystem services (Sekercioglu, 2010). Forest depletion is among the significant environmental problems that threaten and have severe consequences on our environments, decreasing floral and faunal species and putting more pressure on the forest dwellers who depend on them (Katila et al., 2019; Madaki and Sayok, 2019). Food and Agricultural Organization [FAO] (2006), in its assessment of 179 countries in 1990, found that Forests covered somewhat more than 3,400 million ha, or $27 \%$ of world land area, with forests in developed regions accounting for $42 \%$ of total land area compared to 58 per cent in developing regions. The loss of forest land between 1980 and 1990 was estimated to be 163 million ha, with 154 million ha (94.5\%) in the tropics alone, resulting in per capita forest area falling from approximately 1.2 ha in 1960 to 0.6 ha in 1990, with projections of less than 0.2 ha by 2020 . Deforestation can cause various impacts on the environment depending on the existing environmental condition of the area in question (Weisse and Goldman, 2020).

According to the United Nations' Food and Agriculture Organization, an estimated 18 million acres (7.3 million hectares) of forest are destroyed each year (MENA Report (2016), nearly the size of Panama (FAO, 2006). Without sufficient reforestation, it will result in declines in habitat and biodiversity, wood for fuel and industrial uses, and ultimately decreasing quality of life (Bradford, 


\section{Spatio-Temporal Assessment of Vegetation Cover Dynamics in the Kurmi Region of Taraba State, Nigeria}

2018). In addition, forests act as a source of food, medicine and fuel for more than a billion people. (FAO, 2018). Taraba State is one of eight states which account for $50 \%$ of Nigeria's tree cover (Okeke, 2018). In Kurmi, the vegetation cover is mainly of savannah dominated by Daniella, providing a limited amount of shade. In spite of the importance of forest resources to man, the latter also are responsible for degrading forests resulting in multiple societal and environmental problems.

Several studies have addressed the use of GIS and remote sensing in the management and control of vegetation worldwide. Singh (1989), for example, reviewed digital change detection techniques that use remotely sensed data. Coppin \& Bauer (1996) discussed the use of digital change detection in forest ecosystems with remote sensing imagery. Anderson et al. (1976) reviewed some land use and land cover classification systems that can be used in remotely sensed data. Finally, Mahmoodzadeh (2007) used remotely sensed data to monitor green space destruction in Tabriz, Iran.

Adia and Rabiu (2008) applied remote sensing and GIS in how to identify changes that may occur in the green areas. Elias (2005) focused on how to use GIS and remote sensing in the management and survey of natural resources, including natural grassland. Collins, and Woodcock (1996), used several linear change detection techniques for mapping forest mortality using multitemporal Landsat TM data. Rogan et al. (2003) tested remote sensing to monitor Land-Cover Change with classification trees using Landsat TM and ancillary data. Seto et al. (2002) used remote sensing techniques to monitor land-use change in the Pearl River Delta. But there is little or no research using this state of the earth technology (Remote Sensing and Geographic Information System) to better understand the impact of land used land cover in the environmental ecosystem in Kurmi LGA.

Understanding the environmental effects of changes in land use/land cover (LU/LC) is critical for effective natural resource management. Understanding the environmental effects of changes in land use/land cover (LU/LC) is critical for effective natural resource management. This study used a Geographic Information System (GIS) technique to better understand the vegetation index of Taraba State's Kurmi region as well as assess vegetation cover dynamics in Kurmi and its environs using GIS. The specific objectives of this study were to:

i. $\quad$ Analyze the land cover pattern of Kurmi for the year 2009 to 2019

ii. Determine the changes in associated NDVI within the study area

iii. To examine the vegetation cover changes within the study period

In GIS, change detection is a technique for determining how a particular area has changed over two or more time periods; this entails analyzing changes between aerial pictures or satellite images obtained at different times and covering the same geographic area. With this concept, the study used remote sensing images (Landsat TM, ETM+ and OLI) to analyze the Spatio-temporal dynamics of vegetation cover in the Kurmi region of Taraba State with a view to providing a platform for decision making in managing the environment.

\section{MATERIALS AND METHODS}

\subsection{The Study Area}

The Kurmi region of Taraba State, Nigeria lies within $7^{\circ} 00^{\prime}$ to $8^{\circ} 00^{\prime}$ North and $10^{\circ} 00^{\prime}$ to $11^{\circ} 00^{\prime}$ East occupying an area of 4,353 $\mathrm{km}^{2}$ (Figure 1), with an average elevation of $265 \mathrm{~m}$ above sea level, having undulating topography consisting both isolated and chains of mountains across some areas dissected by three main rivers namely River Ndaforo, Bell and Bisaula. River Ndaforo has its source at Fali mountain, flowing southwards to Ndaforo to join River Donga. River Belle starts from Gashaka mountain and flows to the southern part of Abong into River Donga, while River Bissaula starts from Cameron mountain but flows into River Manyan. Rocks in the area consist of glacises, migmatites and metamorphic, exposed on the surrounding hills, usually by streams. The soils are transitional ferruginous tropical varying from clay to loam (below $70 \mathrm{~cm}$ ) and deep (generally over $100 \mathrm{~cm}$ ) except where iron, stones, pans are exposed but are well-drained. Situated in the middle belt, Taraba is affected by tropical climatic conditions characterized by dry and wet seasons. The rainy season starts from March to early November, with maximum rain in August and September, while the dry season starts from late November to early March. Average annual rainfall ranges from 1,200 to $2,500 \mathrm{~mm}$ with a mean annual temperature of $28^{\circ} \mathrm{C}$ (Office of the Surveyor-General Taraba State, 2012). 


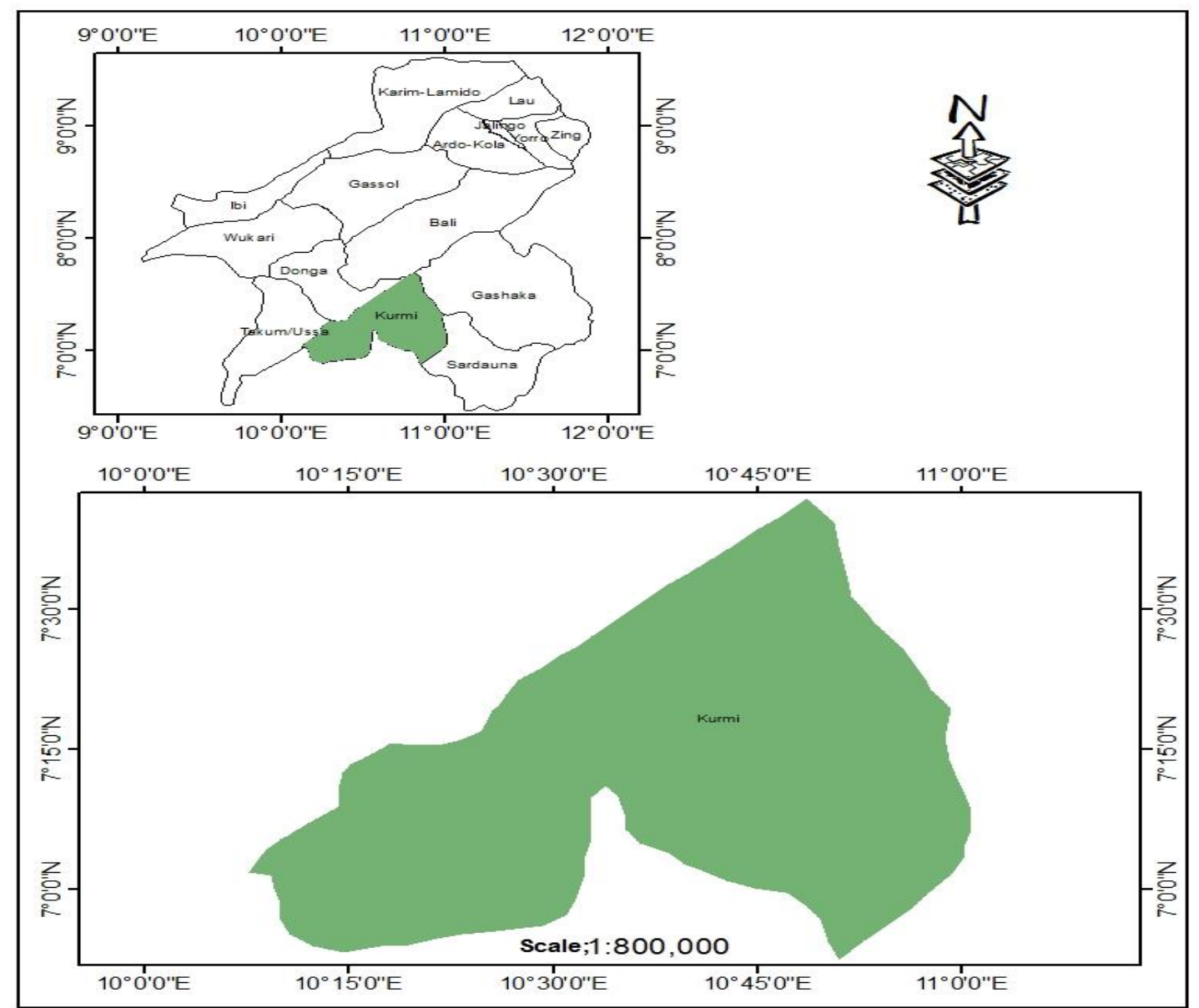

Figure 1: The Study Area

\subsection{Materials and method.}

\subsubsection{Data:}

Landsat TM, ETM+ satellite data was used for this study. These were downloaded from the USGS Erath Explorer website for the years 2010, 2015 \& 2020. The administrative map of Taraba State was derived from the office of the Surveyor-General; Taraba State was used to extract the Study area, which in turn was overlayed on the downloaded Landsat image to mask the study area from the image sensing.

\subsubsection{Pre-processing of satellite image}

The pre-processing of the satellite image is an important technique before the best classification of images for analysis is achieved. Atmospheric correction is performed over all the images using the dark object subtraction (DOS) method using the Semi-Automatic Classification Plugin (SCP) in ArcGIS 10.7.1. DOS is the methodology adopted over other methods because of its simplicity and good result. After atmospheric correction, all the images were subsisted as per the demarcated study area boundary.

\subsubsection{NDVI classification.}

The classification method, especially the most commonly used in deciding different Vegetation indexes (NDVI), is used in this analysis. The classification of Landsat satellite images 3 and 4 bands are used. Landsat TM sensor reflects both near IR in band 4 and visible red $(R)$ in band 3 .

\section{DATA ANALYSIS AND PRESENTATION}

The NDVI has been used widely to examine the relation between Spectral variability and the changes in vegetation growth rate. It is also helpful to determine the production of green vegetation as well as to detect vegetation changes. 


\section{Spatio-Temporal Assessment of Vegetation Cover Dynamics in the Kurmi Region of Taraba State, Nigeria}

\subsection{Normalized Difference Vegetation Index 2010}

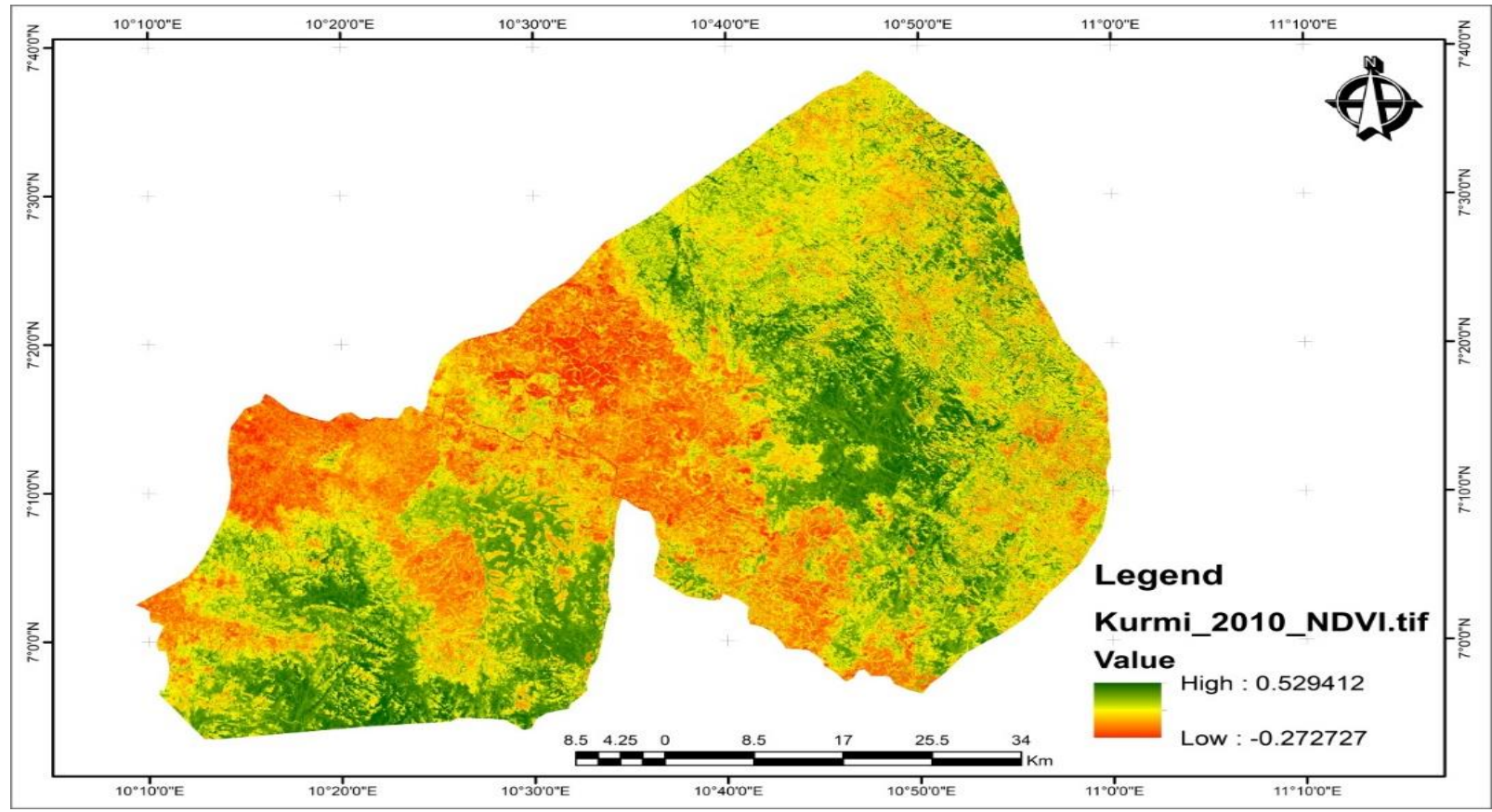

Figure 2: Normalized Difference Vegetative Index of Kurmi Region for the year 2010

Figure 2. shows that the NDVI value of Kurmi in the year 2010 is between -0.2 to 0.5 . The dark green represents dense vegetative cover while red symbology represents No or Low vegetative cover in the Kurmi region. There was a high healthy vegetation index in the northern and southern parts of the Kurmi region with an NDVI value of 0.5 , leaving the central parts of the region with a low NDVI index of approximately -0.3, indicating the effects of deforestation in the area for construction of the built-up environment and agricultural purposes. In addition, it has a far-reaching impact on the region's temperature, rainfall, and wind regime.

\subsection{Normalized Difference Vegetation Index 2015}

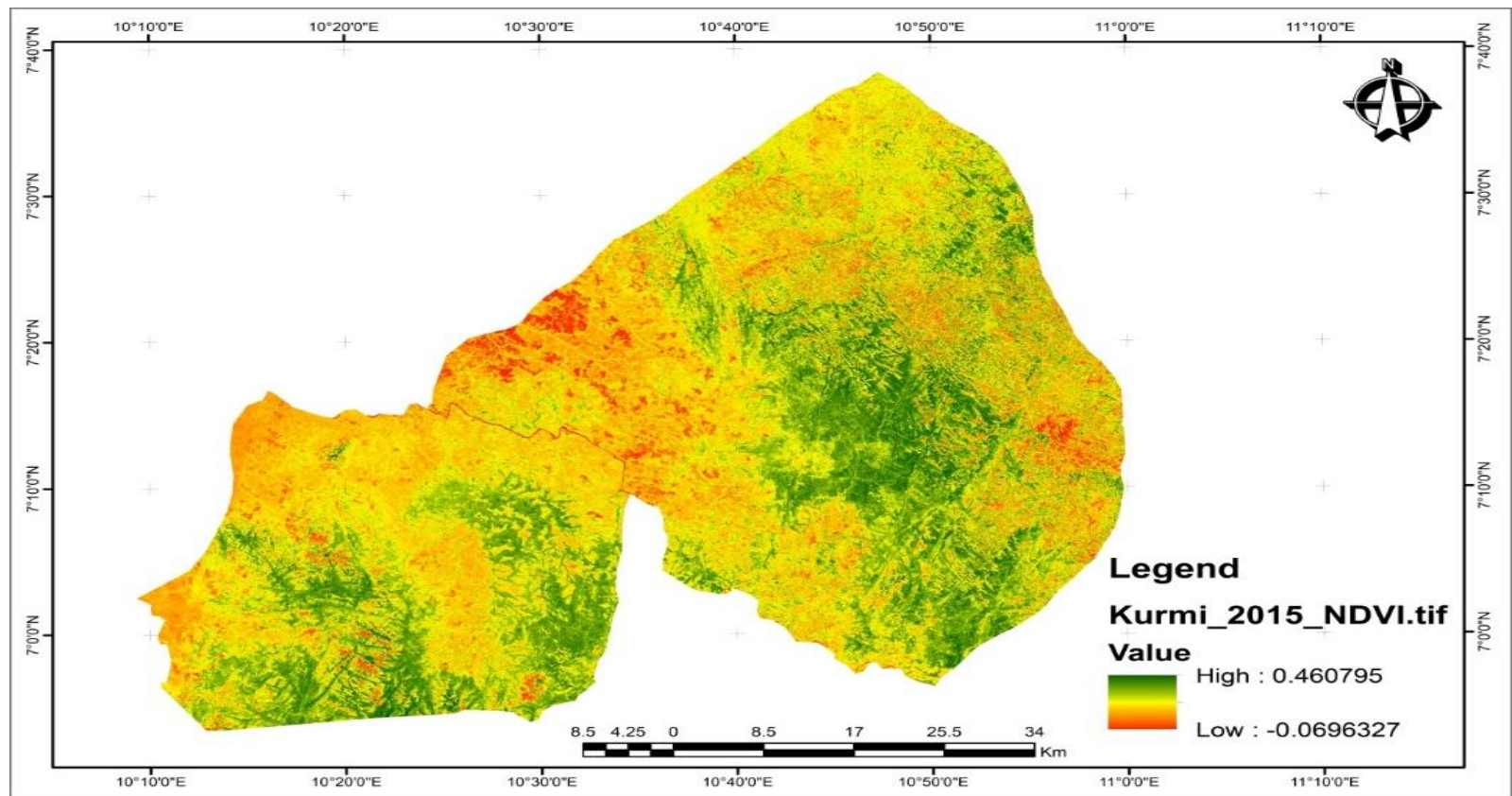

Figure 3: Normalized Difference Vegetative Index of Kurmi Region for the year 2015

Figure 3 shows that the NDVI value of Kurmi in the year 2015 is between -0.0696 to 0.4607 . The dark green represents dense vegetative cover while red symbology represents No or Low vegetative cover of the Kurmi region. There was a healthy vegetation index in the middle of the northeastern and southern parts of the Kurmi region with an NDVI value of 0.4 , leaving the central parts of the region with a low NDVI index of approximately -0.069 , indicating that the effects of deforestation spread further more than 


\section{Spatio-Temporal Assessment of Vegetation Cover Dynamics in the Kurmi Region of Taraba State, Nigeria}

it was in $\mathbf{2 0 1 0}$ for construction of the built-up environment, roads and agricultural purposes. Human activities more impact the areas that are easily accessible. This has a far-reaching impact on the region's temperature, rainfall, and wind regime, which have begun to decline as exacerbated by climate change.

\subsection{Normalized Difference Vegetation Index 2020}

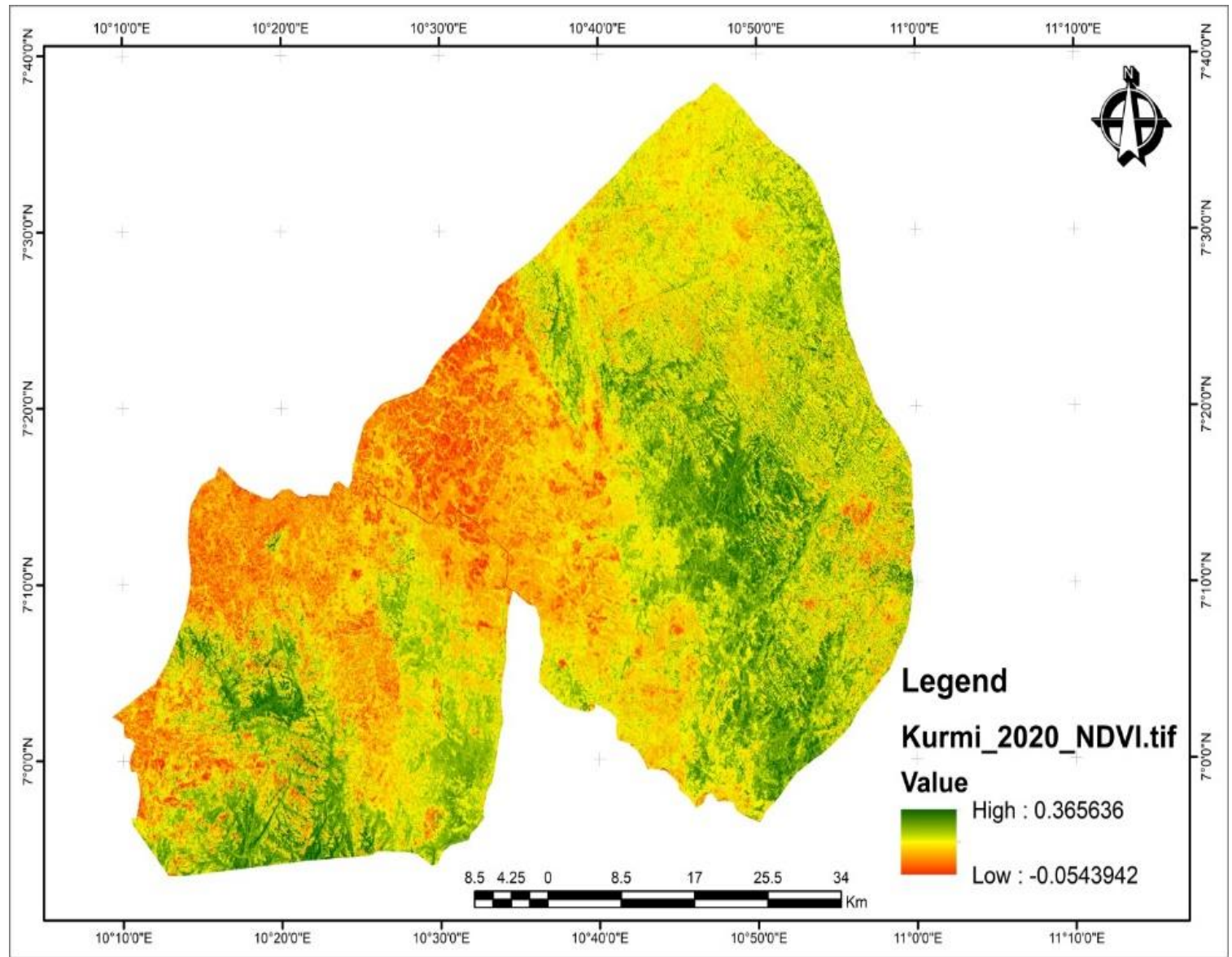

Figure 4: Normalized Difference Vegetative Index of Kurmi LGA for the year 2020

Figure 4 shows that the NDVI value of Kurmi in the year 2020 is between -0.0544 to 0.3656 . The dark green represents dense vegetative cover while red symbology represents No or Low vegetative cover in the Kurmi region. Many parts of the were impacted more by human activities as the health of the vegetation as accessed by the NDVI further reduced. It can be seen that only the middle parts of forests of the Kurmi region still had some healthy vegetations with an NDVI value of 0.3 , leaving the central parts of the region with a low NDVI index of approximately -0.054 , indicating that the effects of deforestation spread further more than it was in 2015 for construction of buildings, roads, agricultural purposes, etc. As in other years of 2010 and 2015, in 2020, the areas that are easily accessible had the more anthropogenic impact on human activities. This has made the region's temperature, rainfall, and wind regime change exacerbated by climate change. Heatwaves and higher daytime and nighttime temperatures in the region were reported in the months of February and March of 2021, and these are attributed to the extensive loss of vegetal cover in the region resulting in most people sleeping outside the homes these months as indoors become extremely warm for weeks.

\section{4 NDVI Classification}

Using NDVI value range

0.1 or Less = Builtup, Barren, Rock, Sand or Snow

0.2 to $0.5=$ Sparse Vegetation (Shrubs, Grassland, Senescing Crops)

0.6 and above $=$ Dense Vegetation.

According to the NDVI analysis, this study area falls within 0.1 and 0.5 that is 2 classes 


\section{Spatio-Temporal Assessment of Vegetation Cover Dynamics in the Kurmi Region of Taraba State, Nigeria}

\subsection{NDVI Classification}

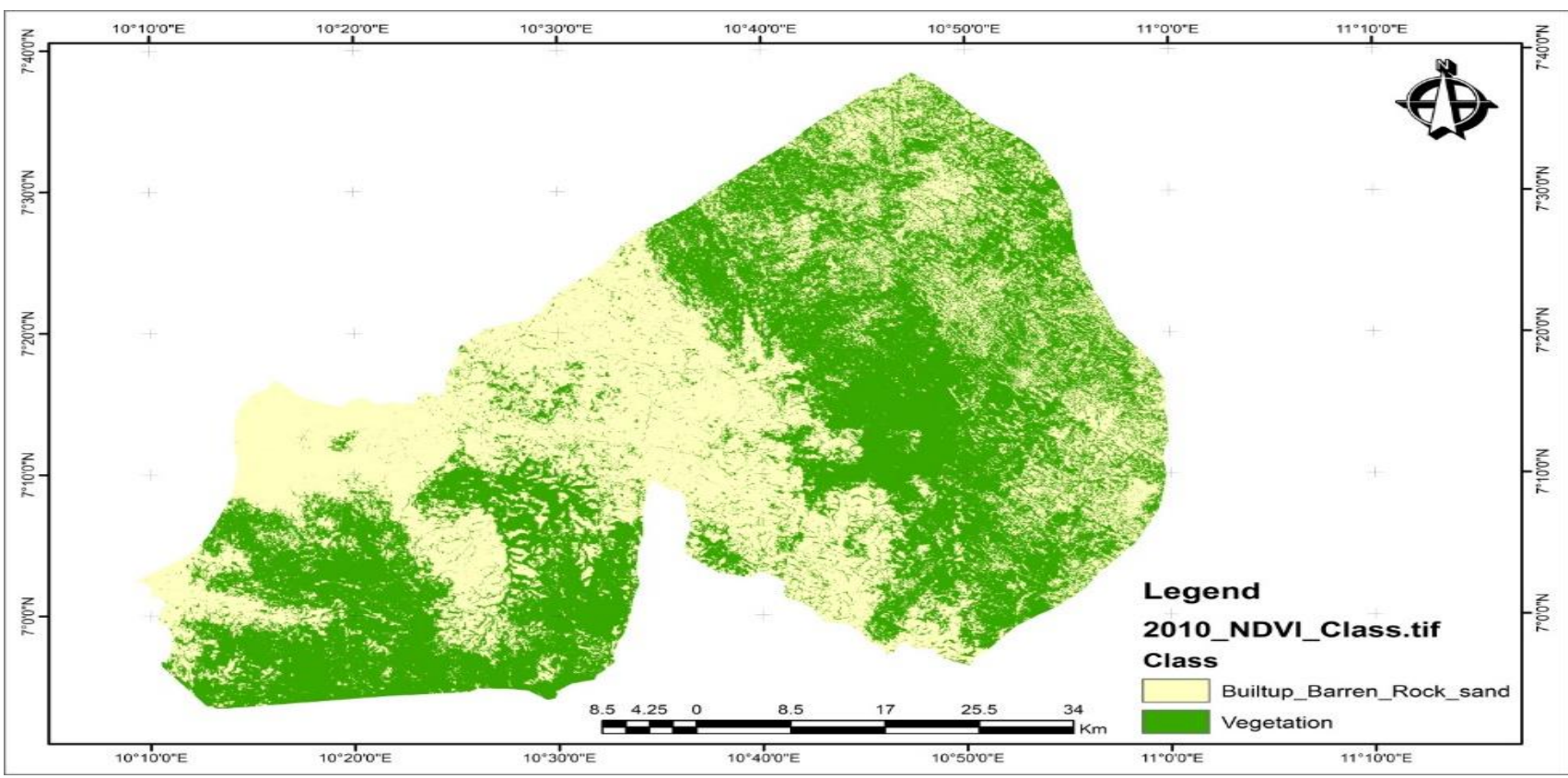

Figure 5: Reclassified Normalized Difference Vegetative Index of the Kurmi Region for the year 2010

Figure 5 shows reclassified NDVI of the Kurmi region in the year 2010. The light-yellow portion represents none vegetative areas (Builtup areas, Barren, Rock and sandy area while the green portion vegetative areas in the Kurmi region of Taraba State.

\subsection{NDVI Classification}

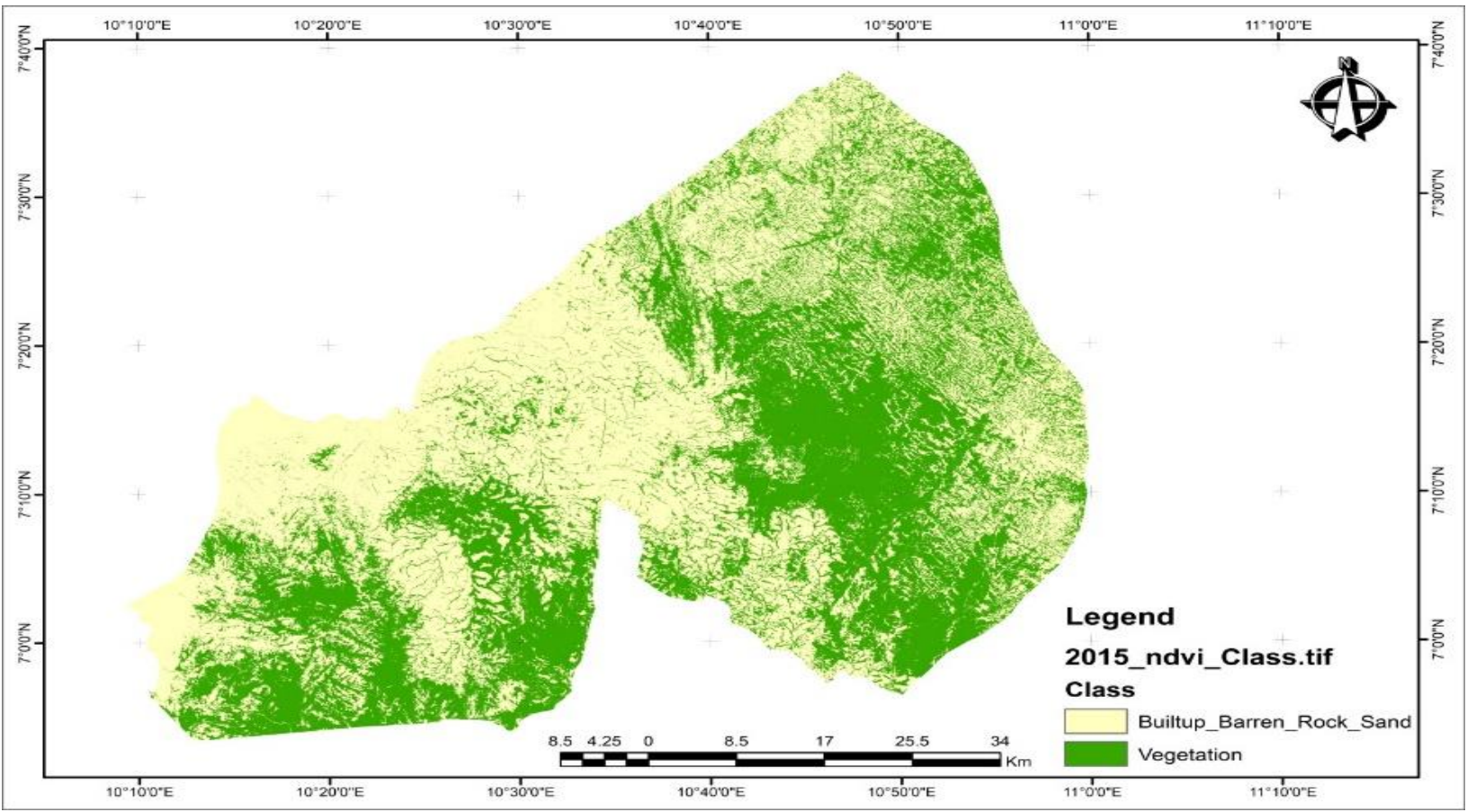

Figure 6: Reclassified Normalized Difference Vegetative Index of Kurmi Region for the year 2015

Figure 6 shows reclassified NDVI of the Kurmi region in the year 2015. The light-yellow portion represents none vegetative areas (Builtup areas, Barren, Rock and sandy area) while the green portion vegetative areas in the Kurmi region of Taraba State. 


\subsection{NDVI Classification}

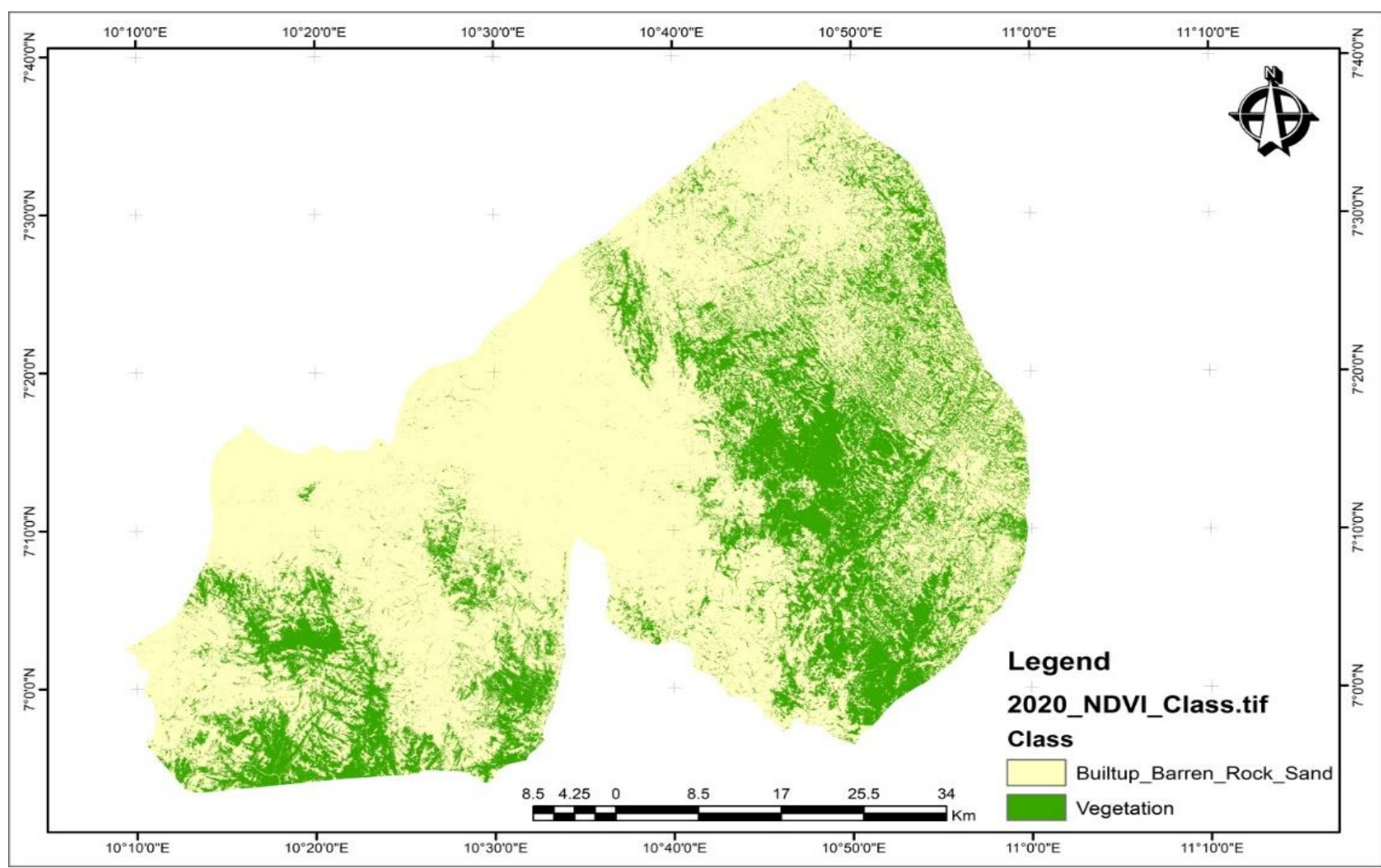

Figure 7: Reclassified Normalized Difference Vegetative Index of Kurmi Region for the year 2020

Figure 7 shows reclassified NDVI of the Kurmi region in the year 2020. The light-yellow portion represents none vegetative areas (Builtup areas, Barren, Rock and sandy area) while the green portion vegetative areas in the Kurmi region of Taraba State.

Table 1: NDVI reclassification of Kurmi from 2010 to 2020

\begin{tabular}{|l|l|l|l|l|l|l|}
\hline \multirow{2}{*}{ CLASS } & 2010 & $\%$ & 2015 & \multicolumn{2}{l|}{2020} & \multicolumn{2}{l|}{} \\
\cline { 2 - 7 } & $\begin{array}{l}\text { AREA } \\
\text { (HECTARE) }\end{array}$ & $\begin{array}{l}\text { AREA } \\
\text { (HECTARE) }\end{array}$ & $\%$ & $\begin{array}{l}\text { AREA } \\
\text { (HECTARE) }\end{array}$ & $\%$ \\
\hline $\begin{array}{l}\text { Builtup, Barren, } \\
\text { Rock, sand }\end{array}$ & 213689 & 49.1 & 239930 & 55.2 & 317944 & 73.1 \\
\hline Vegetation & 221311 & 50.9 & 195069 & 44.8 & 117055 & 26.9 \\
\hline
\end{tabular}

Table 1 shows that in 2010 Built-up, Barren, Rock and Sandy areas covered 213689 hectares with a percentage of 49.1 while Vegetative area covers 221311 hectares with a percentage of 55.2; in 2015, Built-up, Barren, Rock and Sandy areas 239930 hectares with a percentage of 49.1 while Vegetative area covers 195069 hectares with a percentage of 44.8; in 2020 Built-up, Barren, Rock and Sandy areas 317944 hectares with a percentage of 73.1 while Vegetative area covers 117055 hectares with a percentage of 26.9 .

\subsection{Change Analysis}

Change analysis is a Root Cause Analysis technique that uses the precise specification of a single deviation (problem or adverse event) so that changes and/or differences (potential causal factors) can be found by comparison to closely related undeviated situations. 


\section{Spatio-Temporal Assessment of Vegetation Cover Dynamics in the Kurmi Region of Taraba State, Nigeria}

\subsubsection{Change Analysis of 2010-2015}

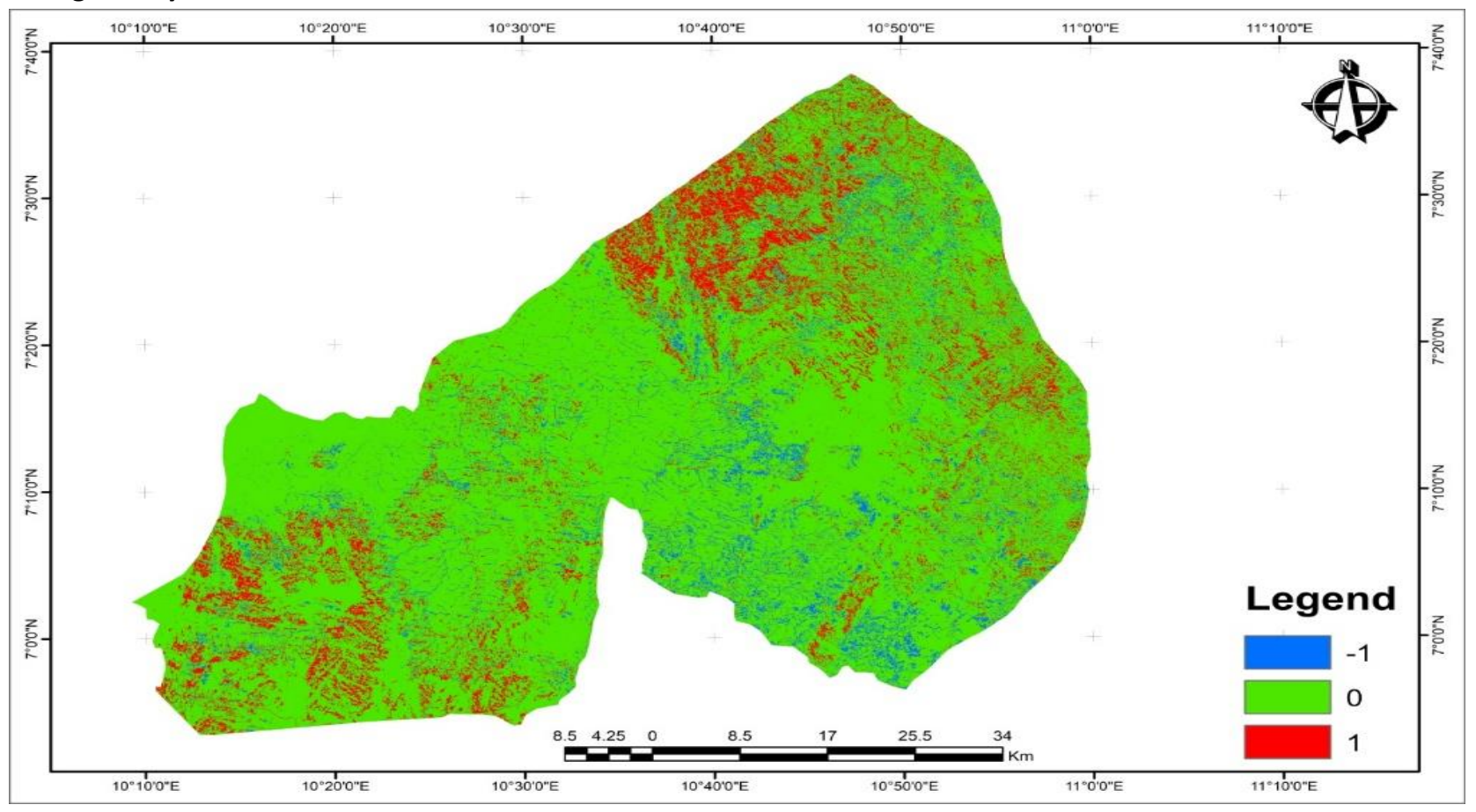

Figure 8: NDVI change from 2010 to 2015 of the Kurmi Region

Figure 8 shows the NDVI change from 2010 to 2015 of the kurmi region of Tarba State in which - 1 represent areas gain in NDVI, 0 represent areas of no change, while 1 represent a loss in NDVI.

\subsubsection{Change Analysis of 2015-2020}

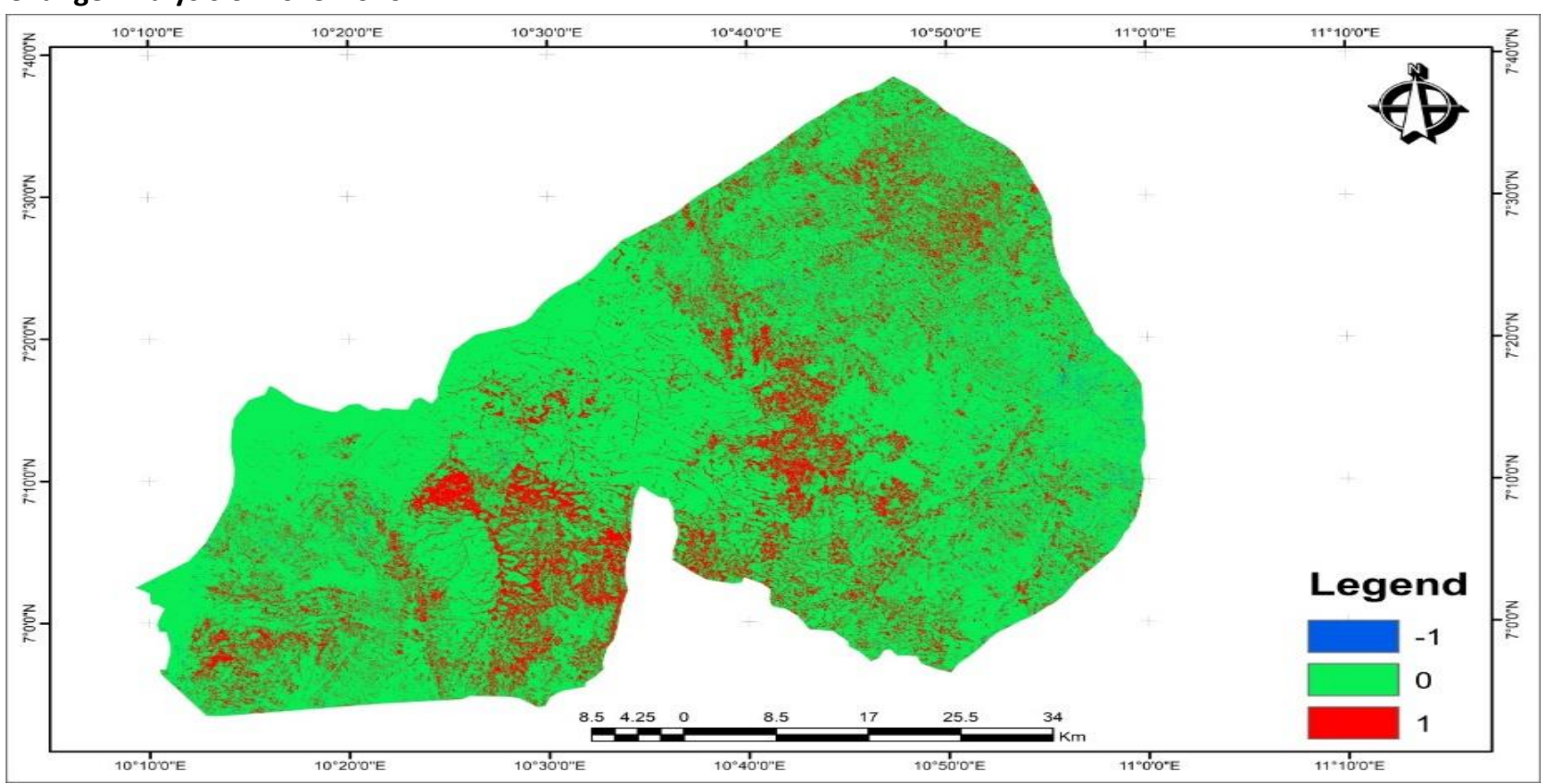

Figure 9: NDVI from 2015 to 2020 of Kurmi Region

Figure 9 shows the NDVI change from 2015 to 2020 of the kurmi region of Taraba State in which - 1 represent areas gain in NDVI, 0 represent areas of no change, while 1 represent a loss in NDVI.

\subsubsection{Change analysis of 2010-2020}

Figure 10 above shows the NDVI change from 2015 to 2020 of the kurmi region of Taraba State in which - 1 represent areas gain in NDVI, 0 represent areas of no change, while 1 represent a loss in NDVI. 


\section{Spatio-Temporal Assessment of Vegetation Cover Dynamics in the Kurmi Region of Taraba State, Nigeria}

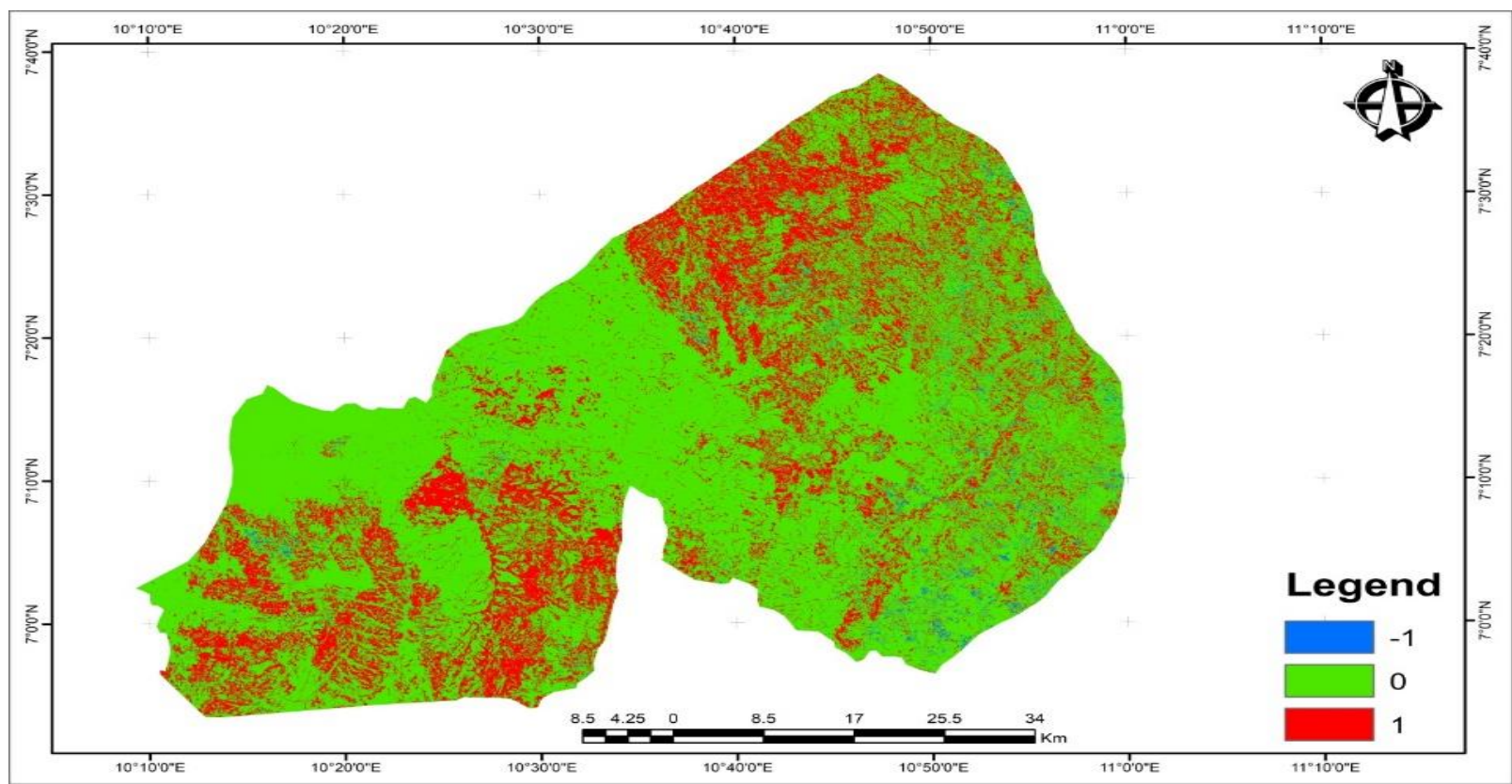

Figure 10: NDVI from 2010 to 2020 of the Kurmi Region

Table 2: showing NDVI Change Analysis

\begin{tabular}{|l|l|l|l|l|l|l|l|l|l|}
\hline \multirow{2}{*}{ CLASS } & \multicolumn{2}{|l|}{2010 to 2015} & \multicolumn{2}{l|}{2015 to 2020} & \multicolumn{2}{l|}{2010 to 2020} \\
\cline { 2 - 10 } & 2010 & 2015 & $\%$ change & 2015 & 2020 & $\%$ change & 2010 & 2020 & \% change \\
\hline $\begin{array}{l}\text { Builtup, Barren, } \\
\text { Rock, sand }\end{array}$ & 49.1 & 55.2 & & 55.2 & 73.1 & & 49.1 & 73.1 & \\
\hline Vegetation & 50.9 & 44.8 & -6.1 & 44.8 & 26.9 & -17.9 & 50.9 & 26.9 & -24 \\
\hline
\end{tabular}

Table 2 shows that from 2010 to 2015, there was an increase in none vegetative areas (Builtup, Barren, Rock, sand) by 6.1\% and reduction of vegetation by $6.1 \%$, also from 2015 to 2020, there was an increase in none vegetative areas (Builtup, Barren, Rock, sand) by $17.9 \%$ and reduction of vegetation by $17.9 \%$, while from 2010 to 2020 there was an increase in none vegetative areas (Builtup, Barren, Rock, sand) by $24 \%$ and reduction of vegetation by $24 \%$. Therefore, the deforestation level in the Kurmi region needs constant monitoring to be able to give quality policy advice.

\section{CONCLUSION AND RECOMMENDATIONS}

\subsection{Conclusion}

The most frequent approaches for detecting and monitoring LULC changes are the NDVI differencing method and the categorization method. The NDVI differencing approach is straightforward to construct and interpret; however, it does not offer entire change direction matrices (Lu et al., 2004), and the index differencing is also subject to registration error (Gong et al., 1992). Comparing two NDVI statistics shows the notable change in agricultural lands area percentage from the NDVI differencing method and classification method are the most common procedures for detecting and monitoring LULC changes. The observed changes varied from one NDVI category to another, with some maintaining a constant change (increase or decrease) over the three analysis periods (2010-2015, 2015-2020 and 2010-2020). Hence, the results of this study confirm that Spatio-temporal assessment of vegetation cover dynamics including NDVI using LANDSAT TM ETM+ and OLI data offer a good potential tool for characterizing and understanding Vegetation changes occurring in transitional areas like in Kurmi Taraba State.

\subsection{Recommendations}

It is recommended that alternative sources of domestic energy should be provided, e.g. kerosene should be provided to the lowincome earners to avoid over-dependence on fuelwood sourced from deforestation. The enabling laws in the state should be strengthened, and the outdated forestry regulations made in the 1970s should be updated to reflect the current realities of climate change. There should be consistent forest monitoring and awareness campaigns in the Kurmi region of Taraba State. 


\section{REFERENCES}

1) Adia S. O \& Rabiu A. B., (2008), "Change Detection of Vegetation Cover, using Multi-Temporal Remote Sensing Data and GIS Techniques"; Map India.

2) Ajiola, F.O \& Ilesanmi, T.E (2017). Deforestation, Food Security and Environmental Sustainability in South-West, Nigeria, 1960-2015. Unilag Journal of Humanities (UJH) Vol. 5 No. 1:206-226

3) Anderson, J.R., Hardy, E.E., Roach, J.T \& Witmer, R.E. (1996). A land use and land cover classification system for use with remote sensor data. A revision of the land use classification system in Circular 671. DOI:10.3133/pp964

4) Bradford, A. (2018). Deforestation: Facts, Causes \& Effects. https://www.livescience.com/27692-

5) Collins J. B., \& Woodcock C. E., (1996), "An assessment of several linear change detection techniques for mapping forest mortality using multitemporal Landsat TM data"; Remote Sensing of Environment, 56:66-77.

6) Coppin, P.R \& Bauer, M.E (1996). Digital Change Detection in Forest Ecosystems with Remote Sensing Imagery. Remote Sensing Reviews 13:207-234 https://www.tandfonline.com/doi/abs/10.1080/02757259609532305

7) Dimitry (2020)-Vegetation Cover - an overview | ScienceDirect Topics. https://www.sciencedirect.com/topics/earth-andplanetary-sciences/vegetation-cover

8) Elias M., (2005), "GIS and Remote Sensing for Natural Resource Survey and Management"; Map Middle East, Dubai (Available online: http://www.gisdevelopment.net/application/environment/overview/me05128.htm , last visited on 30th August 2021).

9) FAO (2006). Deforestation causes global warming. Rome: FAO.

10) FAO (2018). State of the World's Forests 2018 - Key Findings, Secretariat Note. Committee on Forestry, Twenty-Fourth Session, Rome, 16 - 20 July 2018

11) https://allafrica.com/stories/201808270252.html. Accessed on 25th September 2021.

12) Kalaba, F. K., Quinn, C. H., Dougill, A. J. (2012). Contribution of forest ecosystem services to rural livelihoods in Copperbelt's Miombo woodlands, Zambia. Sustainability Research Institute Working Paper 41, University of Leeds.

13) Kalaba, F.K, Quinn, C.H \& Dougill, A.J (2013). The role of forest provisioning ecosystem services in coping with household stresses and shocks in Miombo woodlands, Zambia. Ecosystem Services 5 (2013) e143-e148.

14) Katila, P., Pierce Colfer, C., De Jong, W., Galloway, G., Pacheco, P., \& Winkel, G., eds. (2019). Sustainable Development Goals: their impacts on forests and people. Cambridge, UK, Cambridge University Press

15) Madaki, K \& Sayok, A.K (2019). Effects of Deforestation In Kurmi Local Government Area, Taraba State, Nigeria. Journal of Advanced Research in Social and Behavioural Sciences 14, Issue 1 (2019) 16-28

16) Mahmoudzadeh, H (2007). Digital Change Detection Using Remotely Sensed Data For Monitoring Green Space Destruction In Tabriz. International Journal of Environmental Research (IJER), 1(1), 35-41.

https://www.sid.ir/en/journal/ViewPaper.aspx?id=62260

17) MENA (2016). "Climate Protection through Avoided Deforestation (CliPAD)." MENA Report, Albawaba (London) Ltd., Jan. 2016, p. n/a.

18) Millennium Ecosystem Assessment [MEA] (2005). Ecosystems and Human Well-being. Synthesis World Resource Institute, Washington, DC.

19) Okeke, C. (2018). Nigeria: Is Nigeria Losing War Against Deforestation? 27th August 2018.

20) Paumgarten, F \& Shackleton, C.M. (2011). The role of non-timber forest products in household coping strategies in South Africa: the influence of household wealth and gender. Population and environment volume $33,108$. https://doi.org/10.1007/s11111-011-0137-1

21) Rogan J, \& Chen D. (2004). Remote sensing technology for mapping and monitoring land-cover and land-use change. Progress in Planning. 61:301-325.

22) Sekercioglu, C.H. (2010). Ecosystem functions and services. In: SODHI, N. S. \& EHRLICH, P. (eds.) Conservation biology for all. London: Oxford University Press.

23) Seto K. C., et al. (2002), "Monitoring land-use change in the Pearl River Delta using Landsat TM"; International Journal of Remote Sensing, 23(10):1985-2004.

24) Singh, A. (1989) Digital Change Detection Techniques Using Remotely-Sensed Data. International Journal of Remote Sensing, 10, 989-1003. http://dx.doi.org/10.1080/01431168908903939

25) Weisse, M and Goldman, E.D (2020). We Lost a Football Pitch of the Primary Rainforest Every 6 Seconds in 2019. https://www.wri.org/insights/we-lost-football-pitch-primary-rainforest-every-6-seconds-2019 